\title{
Development and Performance Evaluation of Low HP Tractor Operated Wiper Sprayer
}

\author{
A. Udaybhaskar*, K.V.S. Ramireddy, A. Ashok Kumar and B. V. S. Prasad \\ Department of FMPE, College of Agricultural Engineering, Bapatla, ANGRAU, AP, India \\ *Corresponding author
}

\section{A B S T R A C T}

\begin{tabular}{|l|}
\hline Ke y w o r d s \\
Wiper sprayer, \\
$\begin{array}{l}\text { Spray, Chemical } \\
\text { protection and cost } \\
\text { economics }\end{array}$ \\
\hline Article Info \\
\hline $\begin{array}{l}\text { Accepted: } \\
\text { 04 October } 2018 \\
\text { Available Online: } \\
\text { 10 November } 2018\end{array}$ \\
\hline
\end{tabular}

World crop yields are reducing every year between 20 to $40 \%$ due to the damage wrought by plant pests and diseases. Crop protection is essential to reduce loses of yield. Among all the crop protection methods, chemical protection usage growing effectively as of its immediate action, low cost and reduces human drudgery. Chemical protection of crop carried out by dust or spray form. To spray pesticides on crop, low hp tractor operated wiper sprayer was developed instead of using conventional equipment to reduce operating cost, time and drudgery. In laboratory condition, uniformity coefficient of developed wiper sprayer was found to be $89.9 \%$. The average effective field capacity, field efficiency, fuel consumption and application rate of developed wiper sprayer in the field of groundnut was found to be $0.9072,1.4899,2.0618 \mathrm{ha} \mathrm{h}^{-1}, 80,78.83,77.92 \%, 1.513,1.018,0.815 \mathrm{l} \mathrm{ha}^{-1}$ and 423, 253, $181 \mathrm{l} \mathrm{ha}^{-1}$ at forward speeds of $1.5,2.5$ and $3.5 \mathrm{~km} \mathrm{~h}^{-1}$. Cost economics of developed wiper sprayer was found to be 310.2, 197.61 and $150 \mathrm{Rs}^{-\mathrm{ha}^{-1}}$ at forward speeds of $1.5,2.5$ and $3.5 \mathrm{~km} \mathrm{~h}^{-1}$.Saving of labor cost (\%) and time (\%) over conventional method of spraying found to be $101.5,216.27,316.67 \%$ and $1714,2880,4023 \%$ at forward speeds of $1.5,2.5$ and $3.5 \mathrm{~km} \mathrm{~h}^{-1}$. Operating speed of $3.5 \mathrm{~km} \mathrm{~h}^{-1}$ was given best performance.

\section{Introduction}

Crop yields are reducing every year by pests and disease. Crop protection is essential to reduce loses of yield. At present, the plant protection methods are chemical, mechanical, biological, agronomical and biophysical types. Among these, most preferable one is chemical method of plant protection. India has a large and diverse agricultural sector which requires quite effective methods for spraying pesticides at a desired rate, in minimal time for reducing yield losses. Chemical protection plays a major role in agricultural production because of effective control of pest, disease and weed with minimal time and expenditure. It also reduces the number of labours requirement in the field and reduces human drudgery. Chemical protection is carried out by applying pesticides on crop by sprayers. The main function of sprayer is to atomize the spray fluid and distribute them uniformly over the crop to be protected. Another function is to regulate the amount of pesticides to avoid excessive application that might prove harmful or wasteful. Spraying techniques are 
classified as high volume (>400 $1 \mathrm{ha}^{-1}$ ), low volume $\left(5-4001 \mathrm{ha}^{-1}\right)$ and ultra-low volume ( $<51 \mathrm{ha}^{-1}$ ), according to the total volume of liquid applied per unit of ground area. Farmers generally use lever operated knapsack sprayer, power operated knapsack sprayer, power sprayer and boom sprayer for spraying of pesticides. Knapsack sprayers consist of two adjustable straps for carrying the 10-20 litters tank which may result in back pain. Due to low tank capacity of knapsack sprayer, one person covers less area of land about 0.4 ha day $^{-1}$ (Ojha and Michael, 2016). Lever operated knapsack sprayer requires constant pumping which results in muscular disorder and also cannot maintain desired uniform pressure resulting in an inadequate spraying over the crops.

India is a land of agriculture which comprises of marginal, small, medium and large farmers. In this, marginal and small land holdings contribute 67.10 and $17.91 \%$ for agriculture. In marginal and small holdings, low horse power tractors ranging $18-22 \mathrm{hp}$ are getting popular in India than the large tractors. Development of compactable equipment to low horse power tractors was needed.By considering problems with existing machinery, increasing popularity of small tractors among the marginal and small farmers and to reduce the labour requirement, there is a need for development of low HP tractor operated wiper sprayer.

Keeping the above points in view, the objectives of the present investigation was under taken to develop, evaluate performance and cost economics of wiper sprayer.

\section{Materials and Methods}

Wiper sprayer was developed at Department of Farm Machinery and Power Engineering, College of Agricultural engineering, Bapatla, ANGRAU. Locally available material was used for fabrication of machine to minimize manufacturing cost. Strength of material under the influence of load will help the operator to increase life of the machine (Mada et al., 2013). Design characteristics of various components of developed wiper sprayer are described under the following sections.

\section{Chemical tank}

To develop wiper sprayer, tank was chosen by specifications of mini tractor VST Shakti MT $180 \mathrm{D}$ as its available space rear side and width. Tank is made up of mild steel and its capacity is 2101 , its dimensions are $900 \times 600$ $\mathrm{mm}$. Line diagram of chemical tank is show in figure 1 .

\section{Main frame and hitch system}

The material used for fabrication of the frame was mild steel having $\mathrm{L}$ section of $50 \times 50 \times 5$ $\mathrm{mm}$. The length, width and height from ground of the frame is $1000 \times 400 \times 200 \mathrm{~mm}$. Dimensions of the main frame was taken by the measurements of chemical tank and these are show in figure 2. Hitch system was designed by keeping in view standards for lower and top links of tractor. The isometric view of the frame with three point hitch is shown in the figure 3 .

\section{Boom Stand}

It was part of the main frame which helped in guiding the vertical movement of the boom to adjust spraying height. Two inch square GP pipe are used for boom stand as its light weight and strength. The total height of the boom stand was $1550 \mathrm{~mm}$ from the ground, while in rest condition. Height of the boom stand was taken to avail the spray on most of the field crops and for orchard crop like guava and pomegranate in high density cropping system. High density guava cropping system with $2 \times 2 \mathrm{~m}$ spacing and maximum plant 
height of $1.58 \mathrm{~m}$ was given optimum results (Kumawat et al., 2014). Shading and line diagram of boom stand is show in figure 4 .

\section{Boom}

The total length of boom is $3 \mathrm{~m}$ and boom was divided into three sections viz; central, left and right. The length of the central, left and right boom is $1000 \times 1200 \times 1200 \mathrm{~mm}$. Two inch square GP pipes of two pieces used for center and one and half inch square GP pipes of two pieces are taken to insert in to center booms.

It will provide the adjustment of boom width as required and it is shown in figure 5 .

\section{Power source}

Mitsubishi Shakti MT 180D 4WD mini-tractor was selected as a power source to operate the developed wiper sprayer. It has 3 cylinder, 4 stroke and overhead valve type engine with the output capacity of $18.5 \mathrm{hp}$ at rated 2700 rpm.

\section{Pump}

To operate tractor operated hydraulic sprayer need high pressure of $20-55 \mathrm{~kg} \mathrm{~cm}$ (Surendra, 2011). To meet this required high pressure for spraying, horizontal triplex pump (china) was chosen.

Discharge capacity of pump is $301 \mathrm{~min}^{-1}$ and pump can develops pressure up to $35 \mathrm{~kg} \mathrm{~cm}^{-2}$ at $800 \mathrm{rpm}$. Power required to operate the pump is 2-3 HP. Attaching of pump on main frame is shown in Plate 1.

\section{Spray gun}

Two PTM turbine spray guns ceramic are used for spraying. Spray guns are arranged at ends of the boom with wiper mechanism. Spray gun consists of lever handle at end of the gun to adjust the spray pattern for getting solid and hallow cones in the same gun and it is shown in Plate 2.

\section{Hose pipe}

Two 3 meter hydraulic half inch tubes are used to deliver liquid from pump to spray guns with high pressure.

\section{Wiper mechanism}

Mechanism which convert rotational motion of wiper motor in to back and forth moment of the spray gun with help of four-bar linkage and pivot joints is called wiper mechanism. The simplest and most common linkage is the four-bar linkage. It is a combination of four links, one being designated as the frame and connected by four pin joints. Because it is comprised of four links connected by four pin joints and one link is unable to move. Because the four-bar mechanism has one degree of freedom, it is constrained or fully operated with one driver. The wiper system is activated by a single DC electric motor. The rate of rotation of the motor can be set in accordance with the requirements of the wiping speed to suit the requirements of different occasions (Sharachandra et al., 2015). Different views of wiper mechanism are show in figure 6 .

\section{Wiper Motor}

Monster Guts $12 \mathrm{~V}$ DC Wiper Motor is used for wiper mechanism. It has two operating speeds of 35 and 50 RPM. Power for operating of wiper motor is taken from tractor $12 \mathrm{~V}$ battery. Wiper motor is shown in Plate 3

A model of wiper sprayer was developed by all the compound drawings were made and assembled in Pro-e software for fabrication accuracy, it was shown figure 7. Different fabricated parts and its assembly was shown in Plate 4. 
Performance evaluation of developed wiper sprayer

Performance of developed sprayer is carried out in laboratory and field. Test procedures are discussed in following sections.

\section{Discharge rate of spray gun}

Discharge rate of spray gun is measured at operating pressures of 20,25 and $30 \mathrm{~kg} \mathrm{~cm}^{-2}$ for solid and hallow cone spray patterns. The discharge (v) for each pressure difference was collected for a known time ( $\mathrm{t}$ ) and the rate of discharge (q) was calculated by following formula (Jayashree and Krishnan, 2012).

$\boldsymbol{q}=\frac{v}{t} \min ^{-1}(1)$

\section{Swath width of developed sprayer}

Test is conducted in laboratory conditions in dry sandy soil to reduce effect of wind on swath width of spray and all the experiment is conducted in static position of sprayer. Experiment is conducted with three boom heights of 60,90 and $120 \mathrm{~cm}$ from the ground with three boom widths of 1.6, 2.3 and $3 \mathrm{~m}$ at each boom height with operating pressures of 20,25 and $30 \mathrm{~kg} \mathrm{~cm}^{-2}$. These all combinations are conducted at wiping angles of $20^{\circ}, 25^{\circ}$ and $30^{\circ}$ from the center of gun. Experiment is replicated 3 times for taking of average values.

\section{Uniformity Coefficient of Wiper Spray}

Uniformity coefficient of sprayer was determined in laboratory conditions with static position of wiper sprayer. The area around the spray was divided into squares of equal area. A can is placed at the center of the square which represents the precipitation falling on the area. Spacing between the spray guns is 3 meter apart, so cans are placed half meter apart. Total 78 cans are arranged in trapezoidal pattern with five rows of arrangement in the spray area. Uniformity coefficient is calculated by the following formula (Michael, 2008).

$C u=100\left(1.0-\frac{\sum X}{m n}\right)_{(2)}$

Where,

$\mathrm{C}_{\mathrm{u}}=$ Uniformity coefficient

$\mathrm{m}=$ average value of all observations (average application rate), $\mathrm{mm}$

$\mathrm{n}=$ total number of observations

$\mathrm{X}=$ numerical deviation of individual observations from average application rate, $\mathrm{mm}$

\section{Field test}

Field test of wiper sprayer is carried out at College farm, CAE, Bapatla. Test was conducted in groundnut crop for evaluating the performance of prototype wiper sprayer. Test methods are discussed in following sections. All the tests are conducted at forward speeds of $1.5,2.5$ and $3.5 \mathrm{~km} \mathrm{~h}^{-1}$ to meet requirement of high density crops (Anonymous, 1984).

\section{Theoretical Field Capacity}

For calculating the theoretical filed capacity, working width of sprayer and travelling speed has been taken in to consideration.

It is always greater than the actual field capacity. Theoretical field capacity is calculated by using following formula (Shubham et al., 2018).

T. F. C $=^{\frac{5 \times W}{10}}(3)$

Where, 
T. F. C $=$ Theoretical field capacity, ha $\mathrm{h}^{-1}$

$\mathrm{S}=$ Speed of operation, $\mathrm{Km} \mathrm{h}^{-1}$

$\mathrm{W}=$ Width of spray, $\mathrm{m}$

\section{Effective field capacity}

For calculating effective field capacity, the time consumed for actual work and lost for other activities such as turning and filling the tank of spray was taken in to consideration. Effective field capacity was calculated by following formula (Shubham et al., 2018).

E. F. C $=\frac{A}{T_{p}+T_{n p}}$

Where,

E. $\mathrm{F} . \mathrm{C}=$ Effective field capacity, ha $\mathrm{h}^{-1}$ $\mathrm{A}=$ Area, ha

$\mathrm{T}_{\mathrm{p}}=$ Productive time, $\mathrm{h}$

$\mathrm{T}_{\mathrm{np}}=$ Non-productive time, $\mathrm{h}$

\section{Field efficiency}

Field efficiency will be calculated by taking ratio of effective field capacity to theoretical field capacity. It is always expressed in percentage. It was calculated by following formula (Shubham et al., 2018).

$\mathrm{F}_{\mathrm{e}}(\%)=\frac{\mathrm{EFC}}{\mathrm{TFC}} \times 100$

Where,

$\mathrm{F}_{\mathrm{e}}=$ Field efficiency, $\%$

E.F.C $=$ Effective field capacity, ha $h^{-1}$

T.F.C $=$ Theoretical field capacity, ha $\mathrm{h}^{-1}$

\section{Application rate of developed wiper sprayer}

Spray volume to cover one unit of area depends on discharge rate of nozzle, spacing of nozzles on the boom, nozzle pressure, spray width and forward travel speed. Therefore, it is essential to have a trail run with plain water on small area and records the above mentioned parameters. Based on these parameters, the quantity of spray fluid required per unit area can be calculated by following formula (Surendra, 2011).

$\mathrm{Q}_{\mathrm{a}}=\frac{A \times T_{V}}{T_{a}}(6)$

Where,

$\mathrm{Q}_{\mathrm{a}}=$ application rate, $\mathrm{L} \mathrm{ha}^{-1}$

$\mathrm{A}=$ total area to be sprayed, ha

$\mathrm{T}_{\mathrm{v}}=$ spray volume used on trial plot area, $\mathrm{L}$

$\mathrm{T}_{\mathrm{a}}=$ trial plot area, ha

\section{Fuel consumption}

Fuel consumption $\left(\mathrm{F}_{\mathrm{c}}\right)$ was measured by top fill method. The fuel tank was filled up to its maximum capacity before testing. After spraying operation using test tractor with developed sprayer the fuel tank was filled up to its maximum capacity. The refilled of fuel was measured using measuring jar. Then the fuel consumption was measured using following formula.

$F_{c}\left(\operatorname{Lh}^{-1}\right)=\frac{v}{t}(7)$

Where, $\mathrm{V}=$ volume of fuel consumed, $\mathrm{L}$ $\mathrm{t}=$ total operating time, $\mathrm{h}$

\section{Cost Economics of Developed Wiper Sprayer}

Standard procedure was used for calculating operating cost of wiper sprayer.

\section{Results and Discussion}

\section{Discharge rate of spray gun}

Figure 8 shows the discharge rate of spray gun as 3.6, 3.78, 3.95 and $4,4.445,4.8651 \mathrm{~min}^{-1}$ 
for hallow and solid cone spray at 20, 25 and $30 \mathrm{~kg} \mathrm{~cm}^{-2}$. Discharge rate of solid cone spray is more than hallow cone spray for all operating pressures.

\section{Swath width of developed sprayer}

Table 1 shows that, 9 combinations were shortlisted out of 243 trails on bases of swath width overlap percentage. These all combinations are within the range of $20-25 \%$ overlap, of which first combination with $25^{\circ}$ of wiping angle of spray gun from it centre, 20 $\mathrm{kg} \mathrm{cm}^{-2}$ of operating pressure, $0.9 \mathrm{~m}$ height of spray from ground and boom width $3 \mathrm{~m}$ is the best combination. First combination is given maximum swath width of $9.45 \mathrm{~m}$ with limited percentage of overlap of 20.63 in static position of sprayer.

\section{Uniformity coefficient of wiper spray}

Uniformity coefficient of developed wiper sprayer is $89.81 \%$, which shows the coverage of spraying is uniform. Uniformity coefficient of $85 \%$ or more is considered to be satisfactory (Michael, 2008).

Uniformity coefficient is calculated from equation 2 .

$$
\begin{aligned}
& C_{u}=100\left(1.0-\frac{201.38}{1976}\right) \\
& C_{u}=100(1.0-0.1019) \\
& C_{u}=89.81 \%
\end{aligned}
$$

\section{Theoretical and effective field capacity}

Figure 9 shows that, theoretical field capacity of developed wiper sprayer is varying from 1.134 to 2.646 ha $^{-1}$ and effective field capacity varies from 0.9072 to $2.0618 \mathrm{ha} \mathrm{h}^{-1}$ for forward speeds of 1.5, 2.5 and $3.5 \mathrm{~km} \mathrm{~h}^{-1}$. Field capacity of sprayer was increases with change in forward speed from 1.5 to $3.5 \mathrm{~km}$ $\mathrm{h}^{-1}$.

\section{Field efficiency}

Figure 10 shows that, field efficiency of developed wiper sprayer was varying from 77.92 to $80 \%$ at forward speeds of $1.5,2.5$ and $3.5 \mathrm{~km} \mathrm{~h}^{-1}$.

Field efficiency of sprayer decrease with increase in forward speed, because of increase in theoretical time consumption as increased in speed.

\section{Fuel consumption}

Figure 11 shows that, fuel consumption of developed wiper sprayer was varying from 1.373 to $1.681 \mathrm{l} \mathrm{h}^{-1}$ as change in forward speeds of $1.5,2.5$ and $3.5 \mathrm{~km} \mathrm{~h}^{-1}$ were observed. Fuel consumption increased as change in forward speed due to increasing of speed of operation.

\section{Application rate of developed wiper sprayer}

Figure 12 shows that, application rate of developed wiper sprayer is varying from 181 to $423 \mathrm{l} \mathrm{ha}^{-1}$ at operating pressure of $20 \mathrm{~kg} \mathrm{~cm}^{-}$

2 . Minimum application rate of $181 \mathrm{l} \mathrm{ha}^{-1}$ was observed at forward speed of $3.5 \mathrm{~km} \mathrm{~h}^{-1}$ and maximum of $4231 \mathrm{~min}^{-1}$ at $1.5 \mathrm{~km} \mathrm{~h}^{-1}$. Application rate of sprayer was decreased from 1.5 to $3.5 \mathrm{~km} \mathrm{~h}^{-1}$ operating speed.

\section{Cost economics of developed wiper sprayer}

Table 2 shows that, Cost of operation of developed wiper sprayer decreased with increase in forward speed with values of 310.2, 197.61 and 150Rs. ha ${ }^{-1}$ at forward speeds of $1.5,2.5$ and $3.5 \mathrm{~km} \mathrm{~h}^{-1}$.

Labor required for conventional method (manual spraying) is 2.5 days $\mathrm{ha}^{-1}$ (Ojha and Michael, 2016). So, operating cost of conventional method is $625 \mathrm{Rs}^{\mathrm{h}} \mathrm{ha}^{-1}$. 
Table.1 Optimum combinations of developed wiper sprayer

\begin{tabular}{|c|c|c|c|c|c|c|}
\hline S. No & $\begin{array}{c}\text { Wiping } \\
\text { Angle }\end{array}$ & $\begin{array}{c}\text { Pressure } \\
\mathrm{kg} \mathrm{cm}^{-2}\end{array}$ & $\begin{array}{c}\text { Boom } \\
\text { Height m }\end{array}$ & $\begin{array}{c}\text { Boom } \\
\text { width m }\end{array}$ & $\begin{array}{c}\text { Swath } \\
\text { width m }\end{array}$ & $\begin{array}{c}\text { Overlap } \\
\text { \% }\end{array}$ \\
\hline $\mathbf{1}$ & 25 & 20 & 0.9 & 3 & 9.45 & 20.63 \\
\hline $\mathbf{2}$ & 25 & 20 & 0.9 & 2.3 & 9.25 & 23.24 \\
\hline $\mathbf{3}$ & 25 & 25 & 0.6 & 3 & 8.5 & 23.55 \\
\hline $\mathbf{4}$ & 20 & 30 & 1.2 & 2.3 & 8.27 & 20.95 \\
\hline $\mathbf{5}$ & 20 & 25 & 1.2 & 2.3 & 7.9 & 21.55 \\
\hline $\mathbf{6}$ & 20 & 20 & 1.2 & 2.3 & 7.54 & 22.01 \\
\hline $\mathbf{7}$ & 25 & 20 & 0.6 & 3 & 7.51 & 20.1 \\
\hline $\mathbf{8}$ & 20 & 25 & 0.6 & 1.6 & 7.25 & 22.79 \\
\hline $\mathbf{9}$ & 20 & 25 & 0.9 & 2.3 & 6.8 & 20.62 \\
\hline
\end{tabular}

Table.2 Cost analysis of developed sprayer

\begin{tabular}{|c|c|c|c|}
\hline \multicolumn{2}{|r|}{ Item } & Developed sprayer & Tractor \\
\hline \multicolumn{4}{|c|}{ Fixed cost } \\
\hline 1. & Machine cost, Rs & 19000 & 280000 \\
\hline 2. & Salvage value, $\mathbf{R s}$ & 1900 & 28000 \\
\hline 3. & Depreciation, $\mathbf{R s ~ h}^{-1}$ & 17.1 & 25.2 \\
\hline 4. & Interest, $\mathbf{R s ~ h}^{-1}$ & 5.225 & 15.4 \\
\hline 5. & Taxes, housing and insurance, Rs. $h^{-1}$ & 2.85 & 8.4 \\
\hline \multicolumn{2}{|c|}{ Total fixed cost } & 25.17 & 49 \\
\hline \multicolumn{4}{|c|}{ B. Variable cost } \\
\hline 1. & Repair and maintenance for tractor, Rs. $h^{-1}$ & 9.5 & 28 \\
\hline 2. & Wages, Rs h ${ }^{-1}$ & 18.75 & 31.25 \\
\hline 3. & Fuel charges, & & \\
\hline a. & At speed $1.5 \mathrm{~km} \mathrm{~h}^{-1}$ & & 96.11 \\
\hline b. & At speed $2.5 \mathrm{~km} \mathrm{~h}^{-1}$ & & 106.26 \\
\hline c. & At speed $3.5 \mathrm{~km} \mathrm{~h}^{-1}$ & & 117.67 \\
\hline 4. & Lubrication charges, $\mathbf{R s ~ h}^{-1}$ & & \\
\hline a. & At speed $1.5 \mathrm{~km} \mathrm{~h}^{-1}$ & & 24 \\
\hline b. & At speed $2.5 \mathrm{~km} \mathrm{~h}^{-1}$ & & 26.56 \\
\hline & At speed $3.5 \mathrm{~km} \mathrm{~h}^{-1}$ & & 29.41 \\
\hline \multicolumn{2}{|c|}{ Total variable cost } & 28.25 & \\
\hline \multicolumn{3}{|c|}{$\begin{array}{l}\text { Total cost of operation (Tractor with developed sprayer), } \\
\text { Rs h }^{-1}\end{array}$} & \\
\hline & At speed $1.5 \mathrm{~km} \mathrm{~h}^{-1}$ & 281.42 & \\
\hline b. & At speed $2.5 \mathrm{~km} \mathrm{~h}^{-1}$ & 294.42 & \\
\hline & At speed $3.5 \mathrm{~km} \mathrm{~h}^{-1}$ & 308.42 & \\
\hline \multicolumn{3}{|c|}{$\begin{array}{l}\text { Total cost of operation (Tractor with developed sprayer), } \\
\text { Rsha }^{-1}\end{array}$} & \\
\hline & At speed $1.5 \mathrm{~km} \mathrm{~h}^{-1}$ & 310.2 & \\
\hline & At speed $2.5 \mathrm{~km} \mathrm{~h}^{-1}$ & 197.61 & \\
\hline & At speed $3.5 \mathrm{~km} \mathrm{~h}^{-1}$ & 150 & \\
\hline
\end{tabular}


Fig.1 Line diagram of tank

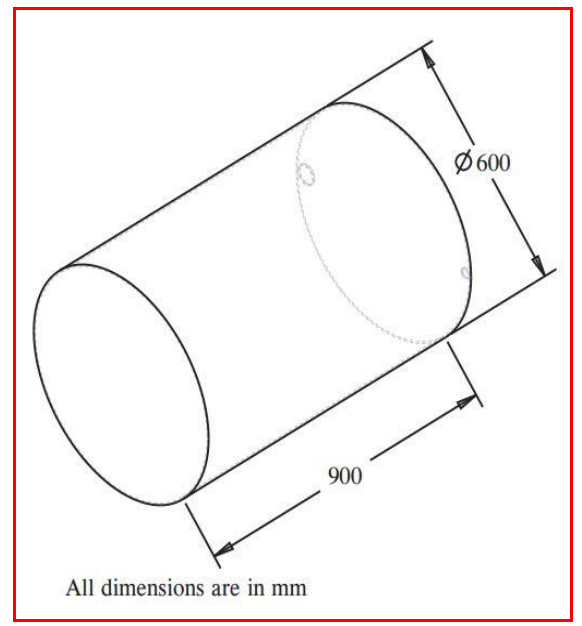

Fig.3 Main frame with 3 point hitch
Fig.2 CAD view of main frame

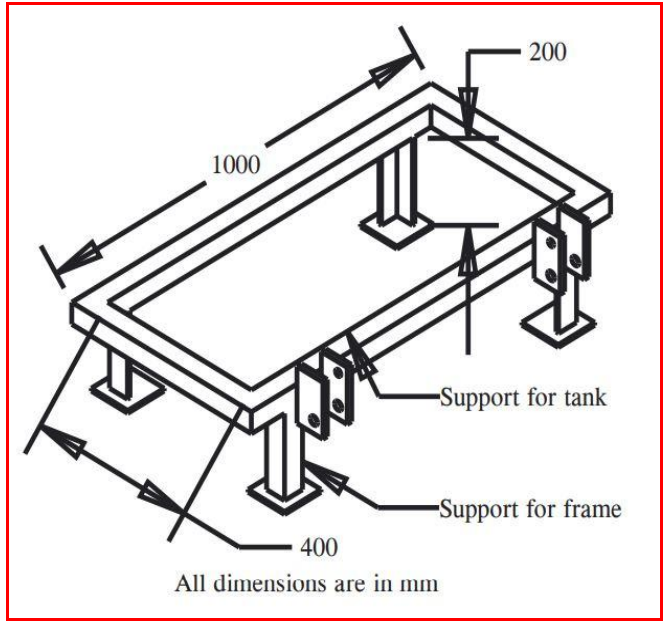

Fig.4 CAD view of boom stand

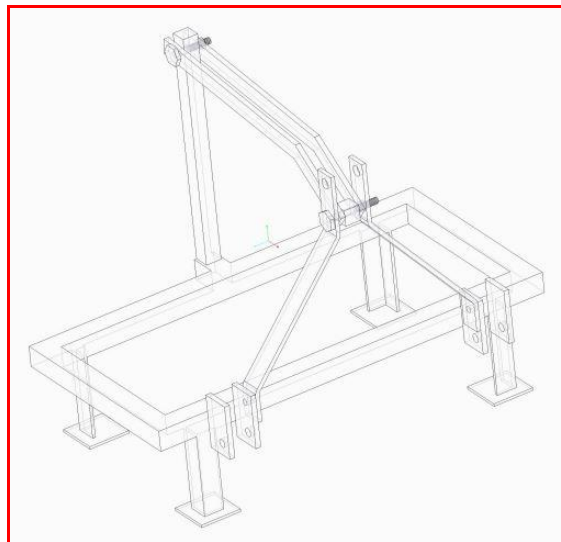

Fig.5 Back view of boom

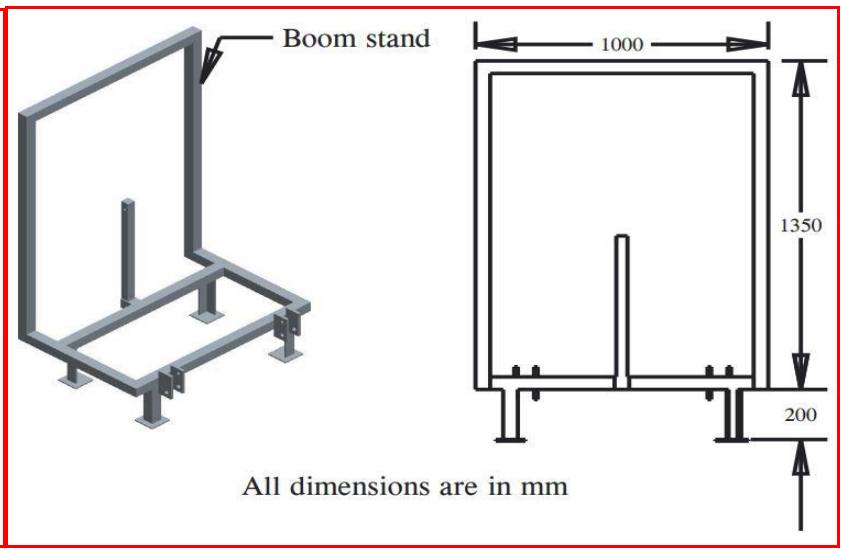

Plate.1 Pump

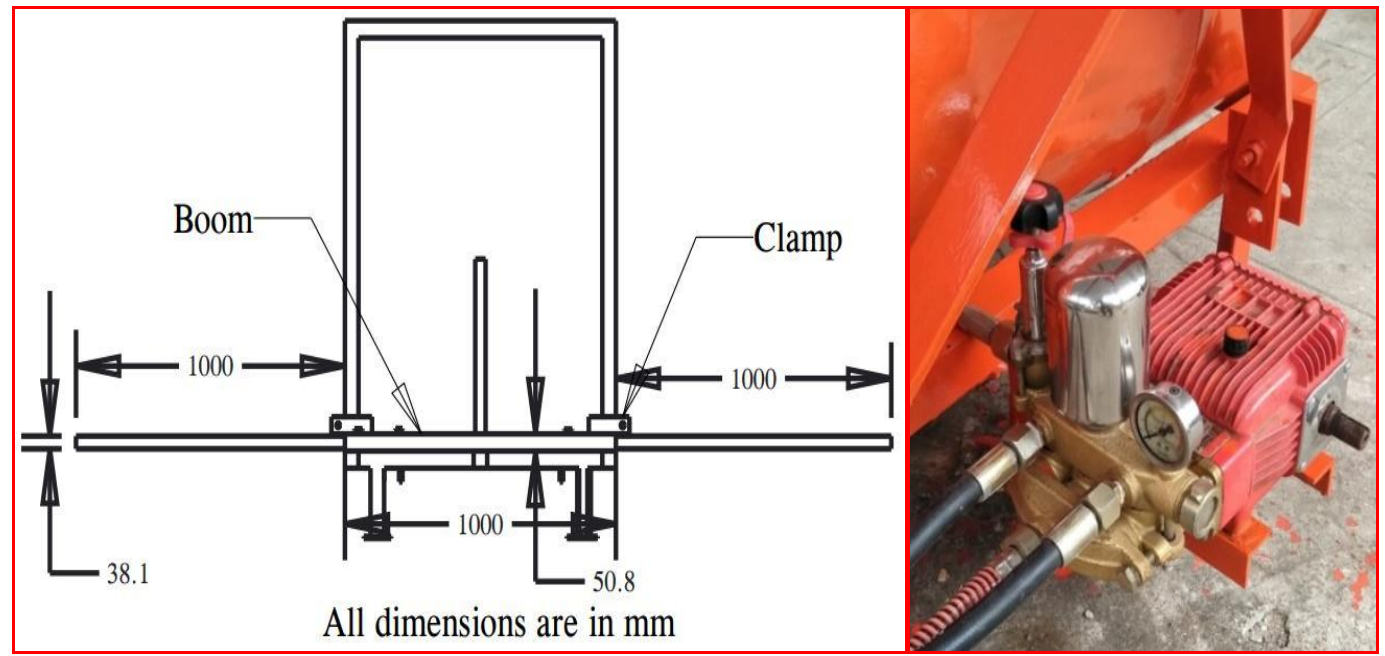


Plate.2 Spray gun

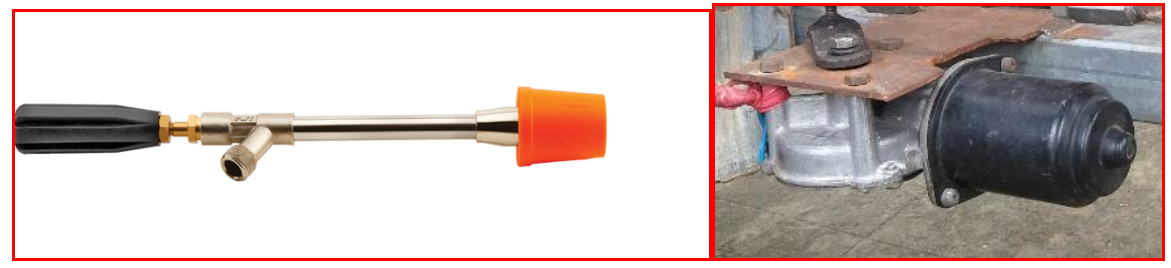

Fig.6 Isometric and top views of wiper mechanism

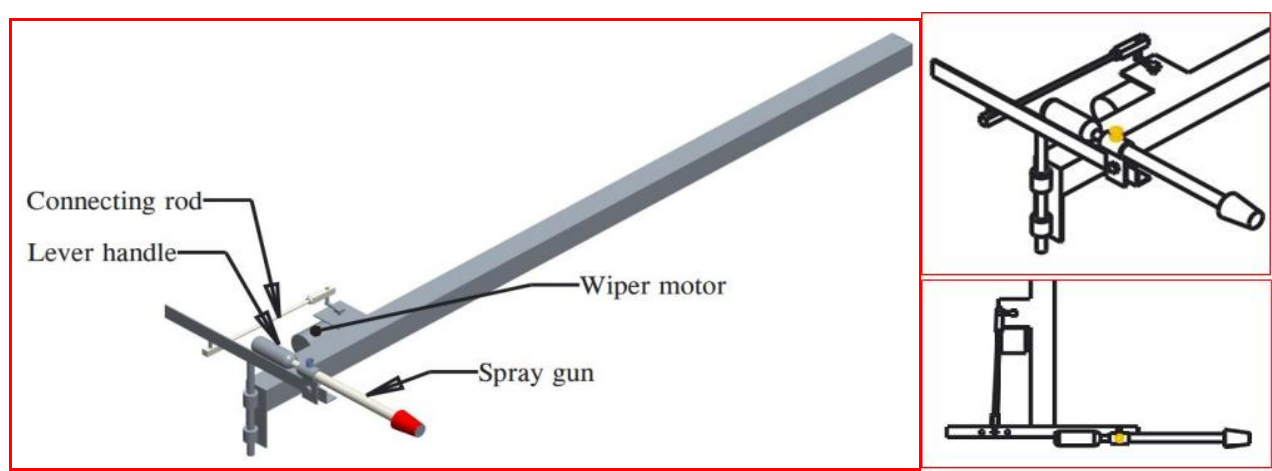

Fig.7 CAD view of developed wiper sprayer

Plate.4 Developed wiper sprayer

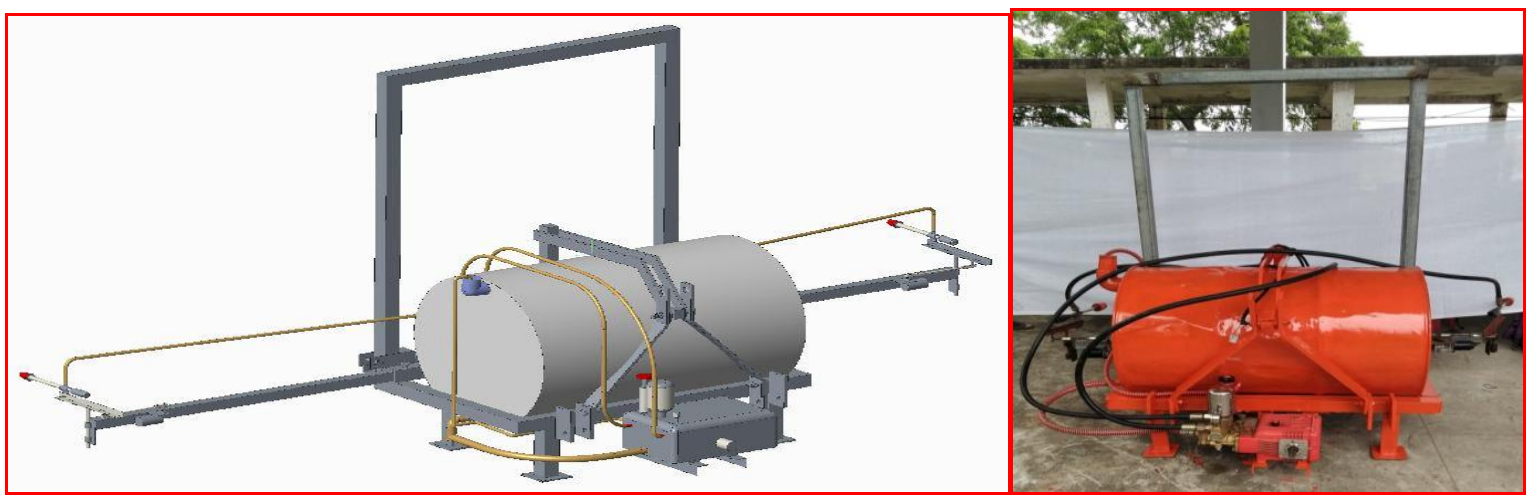

Plate.5 Developed wiper sprayer operating in groundnut field

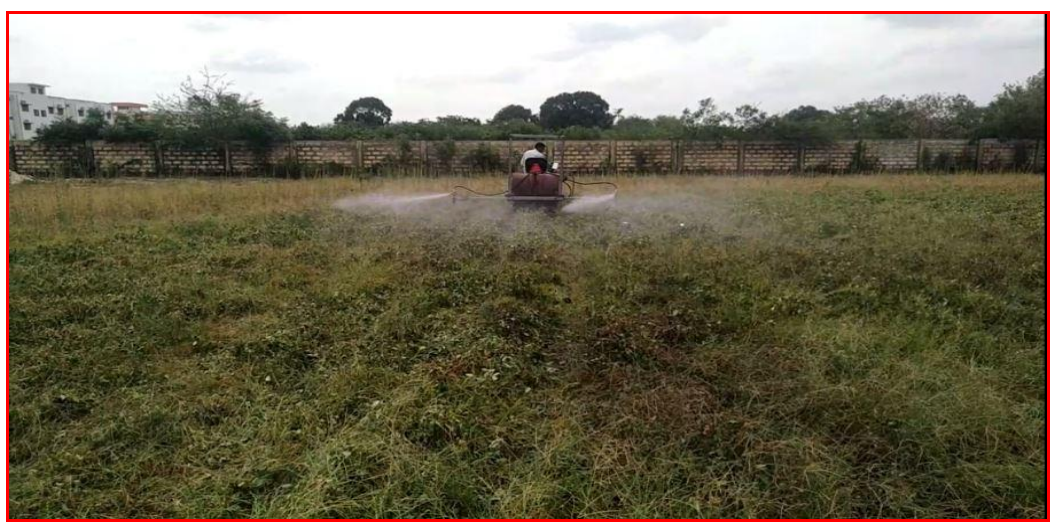


Fig.8 Effect of operating pressure on discharge rate of spray gun

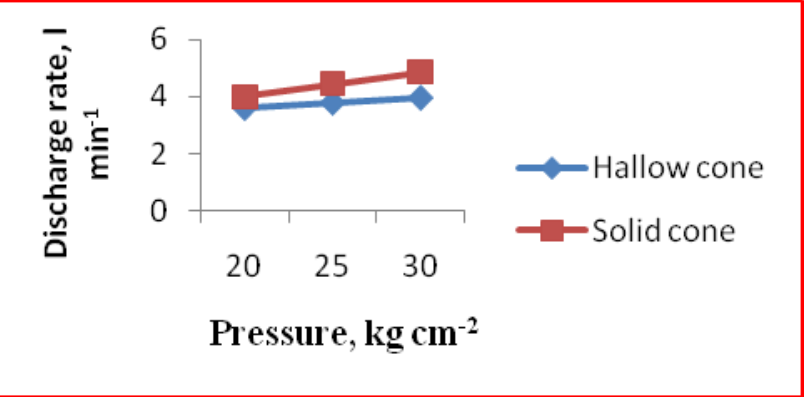

Fig.9 Effect operating speed on field capacity

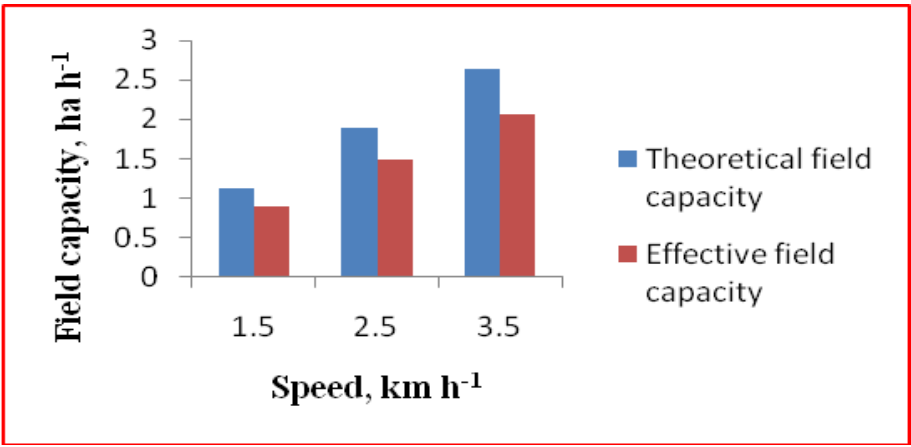

Fig.10 Effect of operating speed on field efficiency

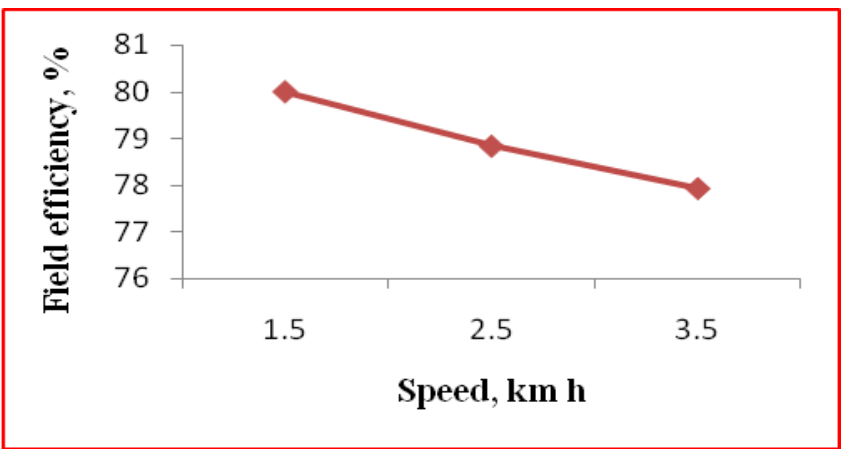

Fig.11 Effect of forward speed on fuel consumption

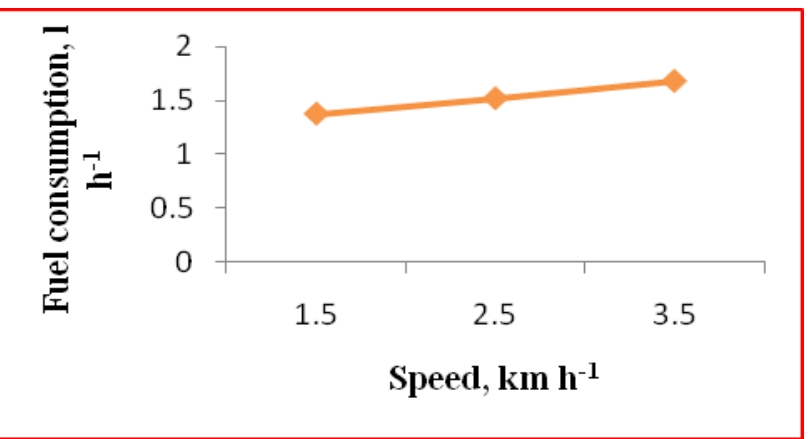


Fig.12 Effect of forward speed on application rate

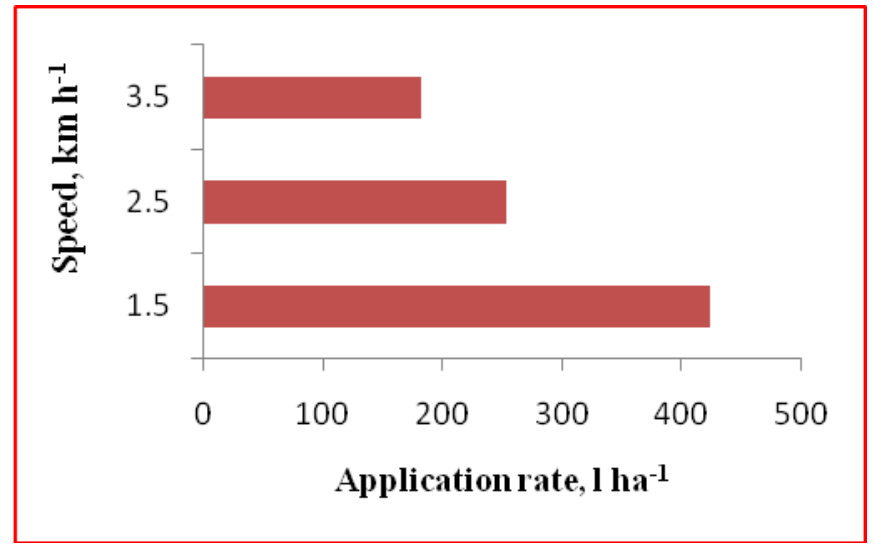

Conclusions are drawn based on laboratory and field test results.

The overall dimensions of developed sprayer were $1600 \times 875 \times 1550 \mathrm{~mm}$ and the weight of machine was $120 \mathrm{~kg}$ and worked satisfactorily

Discharge rate of spray gun was observed as 3.6, 3.78, 3.95 and 4, 4.445, $4.8651 \mathrm{~min}^{-1}$ for hallow and solid cone spray at 20,25 and 30 $\mathrm{kg} \mathrm{cm}^{-2}$.

Hallow cone pattern produced smaller discharge over solid cone.

Optimum condition for developed wiper sprayer with maximum swath width and acceptable overlap percentage was obtained at $25^{\circ}$ of wiping angle of spray gun from it center, $20 \mathrm{~kg} \mathrm{~cm}^{-2}$ of operating pressure, 0.9 $\mathrm{m}$ height of spray from ground and boom width $3 \mathrm{~m}$ with $9.45 \mathrm{~m}$ swath width in static position of sprayer.

Uniformity coefficient of $89.81 \%$ was obtained for developed sprayer in laboratory conditions. This is more than $85 \%$, so spray coverage uniformity of developed sprayer is acceptable.

Effective field capacity of developed sprayerin groundnut crop was increased with increase in forward speed with the values of $0.9072,1.4899$ and $2.0618 \mathrm{ha} \mathrm{h}^{-1}$ at forward speeds of $1.5,2.5$ and $3.5 \mathrm{~km} \mathrm{~h}^{-1}$.

Field efficiency of developed wiper sprayer in groundnut crop was decreased with increase in forward speed with the values of $80,78.83$ and $77.92 \%$ at forward speeds of 1.5, 2.5 and $3.5 \mathrm{~km} \mathrm{~h}^{-1}$.

Fuel consumption of developed wiper sprayer was decreased with increase in forward speed with the values of $1.513,1.018$ and $0.8151 \mathrm{ha}^{-}$ ${ }^{1}$ at forward speeds of $1.5,2.5$ and $3.5 \mathrm{~km} \mathrm{~h}^{-1}$.

Cost of operation of developed wiper sprayer decreased with increase in forward speed with values of $310.2,197.61$ and 150Rs. ha ${ }^{-1}$ at forward speeds of $1.5,2.5$ and $3.5 \mathrm{~km} \mathrm{~h}^{-1}$.

Operating cost of conventional method of spraying is 625 Rs. ha ${ }^{-1}$.

Saving of labor cost (\%) and time (\%) over conventional method of spraying found that $101.5,216.27$ and $316.67 \%$ and 1714, 2880 and $4023 \%$ at forward speeds of 1.5, 2.5 and $3.5 \mathrm{~km} \mathrm{~h}^{-1}$.

Developed wiper sprayer shows the better result with saving of labor cost and time (\%), 316.67 and $4023 \%$ at $3.5 \mathrm{~km} \mathrm{~h}^{-1}$. 


\section{References}

Anonymous. 1984. Myres Technical Manual. Air sprayers and Spraying. F.E. Myers Co., 400 Orange st. Ashland, Ohio.

Jayashree, G.C. and Krishnan, D.A. 2012. Performance evaluation of tractor operated target actuated sprayer. African Journal of Agricultural Research. 7(49): 6605-6612.

Khumawat, K.L., Sarolia, D.K., Kaushik, R.A. and Johda, A.S. 2014. Effects of different spacing on newly planted gaava cv. L-49 under ultra high density planting system. African Journal of Agricultural Research. 9(51): 37293735.

Mada, D.A., Jamala, G.Y. and Ibrahim, S. 2013. Development and performance evaluation of dry cell battery powered ultra-low volume sprayer. The International Journal of Engineering and Sciences. 2(8): 57-61.
Michael, A.M. 2008. Irrigation theory and practice. Vikas Publishing house pvt. Ltd, New Delhi, India.

Ojha, T.P. and Michael, A.M. 2016. Principles of Agricultural Engineering, Vol-1. Jain brothers, New Delhi, India.

Sharachandra, k., Veena, B., Guggari, G.S. and Shivakumar, S. 2015. Design and development of blackboard wiping device. International journal of science and engineering.3: 151-155.

Shubham, R.Z., Surendra, R.K., Manisha, V.G. and Neha, D. 2018. Field and laboratory studies of solarcum hand operated hybrid knapsack sprayer. International Journal of Current Microbiology and Applied sciences. 7(3): 2932-2945.

Surendra, S. 2011. Farm Machinery principles and applications. ICAR, New Delhi, India.

\section{How to cite this article:}

Udaybhaskar, A., K.V.S. Ramireddy, A. Ashok Kumar and Prasad, B. V. S. 2018. Development and Performance Evaluation of Low HP Tractor Operated Wiper Sprayer. Int.J.Curr.Microbiol.App.Sci. 7(11): 3484-3495. doi: https://doi.org/10.20546/ijcmas.2018.711.398 